\title{
MISCELLANEA
}

\author{
Bernard O’Donoghue*
}

\section{THE PARISH AND THE WORLD IN IRISH POETRY}

Keywords: Parish; locality; Ireland; placenames; land; language; history; universality; familiarity

Abstract: Starting with Patrick Kavanagh's distinction between the parish and the province as source and audience for poetry, the essay goes on to Seamus Heaney's essay 'The Sense of Place', to revisit his question of how particular to Irish writing these concerns are. It looks at Irish placenames for their familiarity or obscurity, and the extent to which they can be accounted for by origins in the Irish language or the historical experience of Ireland. It argues that the same questions of fidelity to origin or unfamiliarity arise in the famously successful twentieth-century Irish short story as in poetry, as well as in drama, concluding that this well-worked seam remains strikingly productive.

Even if this is true for 'the great society of mankind' as Smith says, it remains tempting to say that there does seem to be a particular readiness in Irish poetry to introduce local, parochial reference, especially place names (and therefore places though this is not exactly the same) into literary contexts. I am aware that in raising this matter again I am returning to a ground treated decisively by Seamus Heaney in his celebrated 1977 essay 'The Sense of Place', an essay that both gave a new prominence to an aspect of Irish poetry and made it a central point for discussion in the century since. In that essay, Heaney warned that 'this nourishment which springs from knowing and belonging to a certain place and a certain mode of life is not just an Irish obsession, nor is the relationship between a literature and a locale with its common language a particularly Irish phenomenon. It is true, indeed, that we have talked much more about it in this country because of the peculiar fractures of our history, north and south, and because of the way that possession of the land and possession of different languages have rendered the question particularly urgent.' And Heaney goes on to say that the same sense of place and its centrality in the text is true of Dante. Further afield there is the observation by the great Japanese poet Basho, that 'Of all the many places mentioned in poetry, the exact location of most is not known for certain' (said in his Narrow Road to a Far Province in 1689, probably the greatest work in celebration of the local in poetry). I should warn too that at a couple of points I will stray from poetry into other areas of Irish writing, the short story and the drama, but at places where I will claim that they manifest the same concern with judging between the parish and the wider world that Kavanagh does.

\footnotetext{
* Emeritus Fellow, Wadham College, University of Oxford; UK.
} 
Trauma, Narrative, Responsibility

Despite Heaney's salutary warning against taking a universal case to be uniquely Irish, I want to begin with the Irish situation to suggest that there are some ways in which the references to place and local (or parochial) language are particularly compelling there, and maybe to see if the view of it is still the same as it was in 1977 when Heaney set the terms for the discussion of it. By way of final concession, I should say that the features I am going to talk about may well be explained to a considerable extent by what Heaney says about languages and history. But the first thing in Irish practice I want to suggest may be the exception rather than the universal rule is the positive preference for reference to places not already familiar. In general the places mentioned in writing are assumed to be familiar already: Troy, Rome, Egypt, London. When they are novel in the English tradition, they are either explained as new or left unnamed: Gray's ‘Elegy in a Country Churchyard' is set (we know) in Stoke Poges, but it doesn't say so.

Why is the situation different in Irish writing, if it is? And when did it start to be so? Kavanagh himself in his poem 'Epic' says in an ironic opening 'We have lived in important places' and he goes on to name them, claiming a centrality for them comparable to 'the Munich bother' in 1938. It is quite a claim for the parish to claim for Gortin (and in other poems for Inniskeen and Mucker) an importance comparable to the events that precipitated World War II. Yeats of course had similarly given prominence to obscure place-names: 'He stood among a crowd at Dromahair'; 'the hills above Glencar'; Coole. And it is because of the poetry that we know about Alt, a place that is still quite tricky to find - that extraordinary opening of 'Man and the Echo' with its bizarre verb of naming, 'In a cleft that's christened Alt' - and Lissadell, as we also know now about Bellaghy, Castledawson, Magherafelt, Glanmore, Garvaghey, Carrigskewaun, The Moy, Ballygawley, Desertmartin. It is hard to recreate the unfamiliarity these names had before the poets made them so familiar and the literary pilgrims began to make them out. I suspect it would not be so easy to reel off an equivalent list from major poets in English outside Ireland (except possibly from Scotland).

This question of the familiarity of names, though not only with reference to Ireland, is discussed by Heaney in another famous context. In the introduction to his translation of Beowulf he talks about the relative familiarity of classical heroes and Germanic ones.

the classical heritage has entered the cultural heritage enshrined in English so thoroughly that their worlds are more familiar than that of the first native epic, even though it was composed centuries after them. Achilles rings a bell, but not Scyld Scēfing. Ithaca leads the mind in a certain direction, but not Heorot. The Sibyl of Cumae will stir certain associations, but not bad Queen Modthryth.

By analogy, many of the local references in Irish poetry remain obscure, while the canonical texts of English have attained a kind of classical status: Chaucer's Southwerk, or Elsinore, Cawdor and Dunsinane ring a bell, but not yet Gortin or Castledawson or Carrigskewaun.

Heaney was conscious of the demands of the local throughout his career, and his interest often centred on Kavanagh to whose work he credited his own insight that 
it was possible to write poetry about the parish. Kavanagh, as Heaney said, 'wrested his idiom bare-handed out of a literary nowhere.' Heaney ended his early review of the Penguin Book of Pastoral Poetry with regret that instances of pastoral and antipastoral from the twentieth century were not represented more extensively to allow for the anti-pastoral of Kavanagh's 'Great Hunger' or Montague's Rough Field for instance (he could of course have mentioned his own Death of a Naturalist.) This view entails crucially the inclusion of local language (as in both Kavanagh and Montague), and when he considers John Clare in his celebrated essay 'John Clare's Prog', he contrasts Clare's sticking with the dialect word 'prog' for 'prod' -

I found a ball of grass among the hay

\& proged it as I passed \& went away -

with his own removal of the local word 'wrought' from the first line of 'Follower', thus expunging (he says self-castigatingly) its one touch of originality from the poem. Heaney's poem originally began

My father wrought with a horse-plough,

but the verb is changed to the Standard English 'worked' for the London publication in Death of a Naturalist. I will return to Clare at the end by claiming that he experienced the same publishing complexities as befall Irish rural writers like Kavanagh and Heaney.

We already knew that Heaney was sensitive to these idiomatic subtleties. In 'The Sound of Sense', he admires such idioms in Kavanagh's 'Inniskeen Road, July Evening' which he calls 'a love-poem to a place' (Preoccupations, 138), recalling what he had said about the poem in his earlier essay on Kavanagh 'From Monaghan to the Grand Canal' in 1975. He had noted how the adjective 'blooming' at the end of the poem - 'I am king / Of banks and stones and every blooming thing' - 'pulls in two directions at once, faithful to the local and dialect meaning in 'blooming' as a word expressing impatience, and faithful also to the literary charge in it as a word that celebrates growth and flourish'. Heaney goes on to an even more elusive touch of idiom: 'the same vigour comes out in another little word that is like a capillary root leading down into the whole sensibility of Kavanagh's place. In the first line "the bicycles go by in twos and threes". They do not "pass by" or "go past", as they would in a more standard English voice or place, and in that little touch Kavanagh touches what I am circling. He is letting the very life-blood of the place in that one minute incision.'

So why did Heaney not allow the little touch of the parish survive in the case of 'wrought' in his own practice? The issue with 'wrought' is of course much more complicated than his self-accusing judgement suggests; there is another factor here, to do with what Heaney called 'the literariness of the pastoral mode' in his lecture on the 'Pastoral In Extremis'. The word 'wrought' in English generally belongs to poetic diction rather than the language of ploughing, so there is a good reason for changing to the more standard prose term 'worked'. The language of the wider literary world requires the use of a term that avoids the express parochialism of the ploughman's 
usage. Heaney's last word on the matter comes towards the end of Stepping Stones when he answers Dennis O'Driscoll's question about the use of specialised Ulster words in the poems by saying 'I don't have a policy on usage - there's no official linguistic regulator inside me applying a consistent set of rules. It's an on-the-spot business, all depending on whether a word seems to belong or not to belong in a specific context. When I balked at using 'wrought' for 'worked' in 'Follower'... I probably felt, at an unconscious level, that it would be read willy-nilly in a more or less politicised way, not so much a dumbing down of language as a sucking-up. The message would have been, 'See me, I say "wrought”, I belong with the ploughing classes, I know their language': political correctness, old style.'

There are other places in Heaney's poetry where his non-doctrinaire or revisionary view of the claims of the parish is shown in textual emendations. In the first published version of 'The Strand at Lough Beg', the great elegy for Heaney's cousin Colum McCartney, the voice of the poem addresses the murdered cousin:

There you used hear guns fired behind the house (Field Work 17).

But in Opened Ground and all subsequent Selected Poems, the line is emended to the standard language form:

There you once heard guns fired behind the house,

so the parochial is replaced by the standard cosmopolitan. I think this is not a 'provincial' shift in Kavanagh's terms to the linguistic centre; like 'wrought' and 'worked', it rejects the appeal of 'local colour' in the use of the Irish construction (Hiberno-English, to use the clarifying if charmless term) which omits the 'to' of the infinitive after 'used'. There might be something reductive in the use of such vernacular in the stately world of the elegy or panegyric. In fact what Heaney does with that change (which is not to say that we have to approve it) is precisely antiprovincial: he is not afraid to use the standard term when the solemnity of the occasion requires it. In any case, there is no question of denial of the local and parochial in a poem which employs such geographical references as 'Newtownhamilton / Past the Fews Forest', 'Lough Beg' and 'Church Island', and the enormous pathos of

Where you weren't known and far from what you knew.

And of course there are many places where Heaney retains the local idiom ('Go you out to it', in 'Glanmore Sonnets ix' in Field Work for example).

So Heaney's view is not one-sidedly corrective and anti-parochial. In a later poem, 'The Loose Box' in Electric Light, section 2 begins:

On an old recording Patrick Kavanagh states

That there's health and worth in any talk about

The properties of land. Sandy, glarry,

Mossy, heavy, cold, the actual soil

Almost doesn't matter; the main thing is 
Trauma, Narrative, Responsibility

An inner restitution, a purchase come by

By pacing it in words that make you feel

You've found your feet in what "surefooted" means

And in the ground of your own understanding -

Like Heracles stepping in and standing under

Atlas's sky-lintel, as earthed and heady

As I am when I talk about the loose box.

The local can draw on the classical too; there is some reconciliation between the local and the classical in the incorporation of Heracles in support of the surefootedness of the local talk about land. We might read this as another kind of attempt to resolve the 'wrought' issue. It is an interesting argument: 'the actual soil' doesn't matter; it is 'talk' about the properties of land that is so salutary - 'pacing it in words' in the language, spoken or written, in which it is expressed: turning it into literature, we might say.

So, if there is something particular in the Irish case, when did this employment of unfamiliar Irish place-names and usages start, and why? Much has been made in recent discussions of this aspect of Irish poetry - by Heaney and others - as the literary phenomenon in Old and Middle Irish - variously spelt and etymologically analysed called dinnshenchas, recently glossed as 'lore of places'. The element 'dinn' has particular associations with poetry, and seanchas (linked to the compound prefixing element 'sean' (old), means lore of ancient things). In the Introduction to their Oxford edition of the most substantial of the Old Irish epic compilations, Acallam na Senórach (The Colloquy of the Ancients, or Tales of the Elders of Ireland), Ann Dooley and Harry Roe say that that epic is held together by two major literary structures one of which is

'the extremely important genre of the Dinnshenchas collection, the lore of placenames and the sum of underlying stories relating to an area and its name. This is one of the most deeply embedded and persistent strands in all of Irish literature and provides the main structuring device and raison d'être of Tales. In the greatest of early Irish sagas, the Táin Bó Cúailnge (The Cattle Raid of Cooley), for example, many scenes are constructed on just such an aetiological model' (ix).

In the 'Sense of Place' essay, Heaney returns to this, taking a classic aetiological case from the Táin, Ardee in County Louth, which is named (or maybe rationalised) as *Âtha Ferdiad, the 'Ford of Ferdia', Cuchulainn's opponent in the final poignant battle in the Táin.

But the case of the parochial and the authority of the parish is not aetiologicalcausal and explanatory in this sense. In a way it is almost exactly the opposite, in that the point is that it introduces unfamiliar place-names that explain nothing. This too seems to have a long heritage: Whitley Stokes, the authoritative nineteenth-century editor of the Fiannaidheacht texts, was 'disconcerted at not being able to identify any but a few of the place-names'. We are reminded of Basho again. This may be disconcerting, but it also seems to be typical. Flann O'Brien made great play with the onomastics of the Fenian theme in Old Irish in At Swim-Two-Birds: 


\section{Trauma, Narrative, Responsibility}

Who is it? said Finn.

It is Diarmuid Donn, said Conán, even Diarmuid O’Diveney of Ui bhFailghe and of Cruachna Conalath in the west of Erin, it is Brown Dermot of Galway...

Who is it? Said Finn.

It is Caolcrodha Mac Morna from Sliabh Riabhach, said Conán, it is Calecroe MacMorney from Baltinglass. (ASTB, 16)

O’Brien's joke of course is to translate the obscurity of the Irish names into the refined anglicising idiom of South Dublin (as immortalised in the comic tradition by Jimmy O’Dea - 'Thank Heavens we are living in Rathgar').

There are of course celebrated cases where there is an etymological connexion, though sometimes this can be a matter of folk-etymology. John Montague's The Rough Field is a genuinely explanatory case, a translation of the Irish Garbh Faice, translated or transliterated into English as 'Garvaghey', the townland that Montague comes from. Montague wants the sense of roughness to apply to his territory and its political travails. 'The whole landscape', Montague says, was 'a manuscript/ We had lost the skill to read' (The Rough Field, 1972). Equally familiar is Heaney's analysis in the place-name poems in Wintering Out, 'Broagh' and 'Anahorish'. These have been examined with great insight by writers like Tom Paulin (whose own poetic practice I will briefly return to), so I won't dwell on them at any length, beyond noting that both poems begin with a translation of the Irish word that underlies the name (like 'Garvaghey'):

Riverbank ('Broagh' - from the Irish 'bruach’), and

My 'place of clear water’ ('Anahorish’ - from the Irish, something like ‘áit fuar uisce').

In these cases, Heaney spells out the derivations, so they are aetiological, explanatory.

The clearest familiar instance beyond poetry of the aetiological conceit - and its complexities - is Brian Friel's Translations (1980). It can be illustrated throughout the play: to take just one example, there is the debate about the etymology of Burnfoot in Act 2, sc. 1:

YOLLAND: Yes. I'm listening. What do you call it? Say the Irish name again.

OWEN: Bun na hAbhann.

YOLLAND: Again.

OWEN: Bun na hAbhann.

YOLLAND: Bun na hAbhann.

OWEN: That's terrible, George.

YOLLAND: I know. I'm sorry. Say it again.

OWEN: Bun na hAbbann.

YOLLAND: Bun na hAbbann.

OWEN: That's better. Bun is the Irish word for bottom. And Abha means river. So it's literally the mouth of the river.

YOLLAND: Let's leave it alone. There's no English equivalent for a sound like that... 
Trauma, Narrative, Responsibility

OWEN: We are trying to denominate and at the same time describe that tiny area of soggy, rocky, sandy ground where that little stream enters the sea, an area known locally as Bun na hAbhann... Burnfoot! What about Burnfoot?

YOLLAND: (Indifferently) Good, Roland, Burnfoot's good.

OWEN: George, my name isn't...

In this brief exchange there are several things that bear on my theme. Heaney's 'Broagh' ends with the ' $g h$ the strangers found / difficult to manage'; an earlier manuscript version had 'the English' (like Yolland) rather than 'the strangers' finding that difficulty. It is a nice addition to that difficulty that Yolland, who is very well-disposed, can't learn or remember Owen's name either. Without going too deeply into phonetic analysis it is striking that Friel has to misrepresent the normal written form of 'Abhann' before Yolland can pronounce it. It has often been noted that 'Broagh' begins with a remarkable series of words derived from Irish, Old English (docken), and Scots Gaelic (rigs) - all the components of Ulster-Scots. 'Burnfoot', a similar Scots-Old English compound, is an aetiological formation linked to its Irish antecedent in meaning rather than in phonetic structure. Moreover, the ground as described by Owen is remarkably like the properties of land extolled by Kavanagh which Heaney will note in 'The Loose Box'.

What I am primarily concerned with today though are the cases where place references retain their unfamiliarity, resisting transparent translation. So, drawing back from dinnshenchas and the realms of Old Irish (which is a pretty distant relative), there is a surprising predecessor in English poetry, long before the twentieth century, and in a poet whose connexion with the Irish tradition is accidental, if not positively inimical, Edmund Spenser. His poem 'Colin Clouts Come Home Again' (1595) puts the area around his castle of Kilcolman, near Buttevant in North Cork, on the map - and literally on the literary map. Here is the extensive and remarkably parochial passage:

Old father Mole, (Mole hight that mountain gray

That walls the Northside of Armulla dale)

He had a daughter fresh as floure of May,

Which gave that name unto that pleasant vale;

Mulla, the daughter of old Mole, so hight

The Nimph, which of that water course has charge,

That springing out of Mole, doth run downe right

To Butteuant, where spreading forth at large,

It giveth name vnto that auncient Cittie,

Which Kilnemullah cleped is of old:

Whose ragged ruines breed great ruth and pittie,

To travailers, which it from far behold.

Full faine she lou'd, and was belou'd full faine,

Of her owne brother river, Bregog hight,

So hight because of this deceitfull traine,

Which he with Mulla wrought to win delight.

But her old sire more carefull of her good,

And meaning her much better to preferre, 
Trauma, Narrative, Responsibility

Did thinke to match her with the neighbour flood,

Which Allo hight, Broad water called farre... (105-24)

We recognise this of course as the kind of mythological geography we see in Milton's Sabrina; it is what the poem's Penguin Classics editor Richard McCabe calls 'an aetiological fable'. But there is a very substantial set of undigested names here unfamiliar both geographically and linguistically. Mole, McCabe says, is the range of Ballyhoura and Galtee mountains to the North of Spenser's castle at Kilcolman; the Mulla (linguistically related to 'Mole' in Irish, and to 'Armulla' as Spenser says) is the river Awbeg (Abha Beag), 'small river', a tributary of the *Awmoor, 'big river', the 'Abha Mhór' in Irish, the Munster Blackwater known in English in Spenser's time as the 'Broadwater'. The nymph-river Mulla is the sister of Bregog, whose name relates to 'bréag', a lie, so it means deceitful (as the next line says).

The most remarkable name in fact is Buttevant itself, Spenser's local town, which he knows was 'Kilnemullah cleped of old': as indeed it is still, in Irish - Cill na Mullach, probably 'the church of the summits or tumuli' from the ecclesiastical Latin Ecclesia Tumulorum. The strange English name dates at least back to the time of Edward III when the area was granted to the Barry family whose Norman battlecry in the late $12^{\text {th }}$ century was the French phrase 'boutez en avant' - an etymology that led to place names like Boutavant on the Seine. So, in a way, that modest town now has two impenetrable names, unanalysable in English, through Irish and French. The neighbouring town Charleville (founded in 1661 by Richard Boyle, Earl of Orrery, and named after Charles II to mark the Restoration) is similarly non-transparent: its Irish name Ráth Luirc has no connexion with the English one. There was a brief attempt in the middle of the twentieth century to establish 'Ráth Luirc' (or 'An Ráth', the fort) as the normative name in English, but Charleville was too well founded. (This is not always the case: a village on the Cork-Kerry border near where I come from was called (King) Williamstown in my childhood, named after King William III there is a famous emigrant song of that name - but it has now been effectively replaced by the Gaelic-originating Ballydesmond, by which it was officially renamed in 1951. By now - somewhat paradoxically - only old people like me remember the earlier, wholly English name.) Spenser's poem was dedicated to Walter Raleigh, Spenser's friend who lived in Youghal, Co Cork, so some local interest might be predictable. But the poem was published in London, and this wealth of geographical detail might be more than any readership might want or expect.

I have dwelt on it at some length to show where the pursuit of the unfamiliar and the parochial can lead us, and because it bears out what Heaney says about language, land-possession and history in 'The Sense of Place'. Before returning to modern poetic practice again, as a crucial context for the local in modern Irish poetry, we might note that comparable debate about the province and the parish arises with the Irish short story: perhaps in the short story worldwide. In his introduction to the Collected Stories of Frank O'Connor (Vintage 1981), Richard Ellmann says that O'Connor writes about 'a provincial culture in terms that are less provincial, but never cosmopolitan', at a moment when that culture's 'fabric was being slowly torn by modern conditions'. O'Connor's famous study of the short story is called The Lonely Voice, suggesting the story's outlying nature as a form. Ellmann relates this to what 
he calls 'localisms' in linguistic usage, saying that O'Connor's text 'tingles' with them: 'while the life was in her', 'giving him the hard word' and so on. The great celebrant - and practitioner - of the short story in these terms is John McGahern. 'I think of Mohill as one of the happiest towns in the world'. This predilection for the local is well established in Irish writing before McGahern of course, particularly in relation to Kavanagh's parochial-good: provincial-bad binary (though in Kavanagh's case it was expressed much less lyrically ). McGahern's insistent statement and restatement of the values of the parish have become very familiar: 'The local, when the walls are taken away, becomes the universal.' (Love of the World, 2009)

I want to consider briefly the language used to express the short story's localism. What exactly is local about McGahern's language? It is not the language of Co Leitrim particularly, because, although McGahern's references have the descriptive and evocative-of-place power of the greatest poets of locality, the expression of it is not localised. Can an impression of locality be given without representing local language faithfully and phonetically? There is another wider question here - the Dickens issue of how to register 'page dialect', the use of spellings like 'woz' as a kind of trigger to prompt readers to translate into phonetic dialect in their heads - the question of the feasibility or literary usefulness of dialect in serious writing.

Though this is not my main subject here, it is interesting in this connection to compare briefly the practice of O'Connor and McGahern here. In O'Connor's story 'The Majesty of the Law', a police sergeant is very disinclined to perform his unavoidable duty of arresting a local farmer who has been found guilty of affray, a reluctance which is evident from the local language of familiar warmth he and the man he is to arrest both use.

\footnotetext{
'Begor, Dan,' said the sergeant, 'tis younger you're getting.' 'Middling I am, sergeant, middling', agreed the old man in a voice which seemed to accept the remark as a compliment of which politeness would not allow him to take too much advantage. 'No complaints.' 'Begor, 'tis as well because no one would believe them. And the old dog doesn't look a day older.'

'Ah, sha, what do you want going at this hour for?' protested the sergeant with a wave of his hand.
}

The language of the brief second extract here is particularly striking, requiring the reader to read aloud to hear the idiom. Insofar as such a thing is possible, it seems a totally authentic phonetic representation ('Ah, sha, what do you....' represents 'Ah, sure, what do you....'). 'What do you want going' is a faithful representation of nonstandard local syntax, like Heaney's ‘you used hear guns' (in a story first published, I think, by Methuen in London). But the language of narration - 'a compliment of which politeness would not allow him to take too much advantage' - contrasts with the local dialect by employing a positively exalted register of Standard English. It is the language of the wider world: the language that the non-parochial writer has to be versed in - a kind of Dickensian counterpoint. 
Trauma, Narrative, Responsibility

McGahern often insisted on the virtue of an attempt to return to a state of lost innocence, to the parish (usually associated with his mother, as it was by O'Connor); in his later writing in particular, this simplicity, the 'true work' he finds in An tOileánach, the Blasket Island memoir of Tomás Ó Criomhthain, has major emphasis. In 'The Sense of Place' Heaney contrasts Kavanagh's retention of local syntax ('go by' and so on) with Synge's 'ritualized Irish speech'. But elsewhere in the essay on An tOileánach, McGahern approves something like ritualization of speech: 'There is a haunting phrase that echoes like a refrain [in An tOileánach] throughout, lá dár saol é. Flower translates it simply as "a day of our lives”, but it is probably untranslatable.' But in McGahern's story 'The Creamery Manager' this untranslatable phrase occurs twice, translated into English. Guard Casey says 'You gave us a great day out, a day out of all of our lives' (373). Earlier in the story, Jim, the Sergeant, thanks the creamery manager with the same term: 'It's a day out, a day out of all of our lives' (368). Dennis Sampson called McGahern 'a poet who happens to write in the medium of realistic prose', like the narrator's voice in O'Connor. This is a good description of what is going on here: realistic prose is the language of the centre, but this kind of untranslatable prose (like O'Connor's sergeant's 'Sha') might seem to occur more naturally in poetry.

So the phrase McGahern homes in on is clearly not a genuinely observed idiom, taken from local usage, but an attempt to translate what he says is the untranslateable. 'The speech my mother gave me was the English spoken on the Iron Mountains. That language still contained within it at least the ghost of the Irish language. It was a slow, careful, humorous speech, grounded and practical, with a strong Northern accent, its rhythms almost entirely Gaelic, and Gaelic words were retained in the English usage....As my mother's speech was refined by education, my speech was probably tempered in turn by an indiscriminate reading of books in English and by the prayers and ceremonies of the Catholic Church'. This is the process by which the standard language invades the parish; the crucial point is that McGahern does not resent or regret this invasion: his mother's 'indiscriminate reading of books in [Standard] English' or the general learning of the rich and ceremonial language of the Catholic Church. McGahern is extolling a kind of Edenic language as he sees it represented in An tOileánach. But of course the highly craftsmanly McGahern is not the kind of writer who can be accounted for wholly by reference to any tradition or point in time. His language is his own, drawing on all the traditions that he mentions in the Ó Criomhthain essay: local reference and stories in the oral tradition, mediated through the language of the English novel, of the Irish language, of the Catholic liturgy, and any other linguistic source of richness.

Representational and non-representational writing work together to achieve what Richard Ford in his introduction to the Granta Book of the American Short Story calls - brilliantly I think - 'unsettlement'. National character - and McGahern says exactly this, in his remarks about Mohill and the local - becomes obsolete in defining the form: 'the Irish short story', or 'the American', or the 'Canadian' are all dispensed with (to take three places where the short story has been especially successful). I am leaving the short story now; but I think the classic observations about it - O'Connor's 'The lonely voice' for example, as well as Ford's 'unsettlement' - correspond closely to the kind of confinement, for good or ill, that the localism of the parish imposes on 
Irish poetry. We find too the same pros and cons in weighing the local/parochial against the literary.

I want to turn briefly now to poetry in the Irish language where the language and the subject are more fully of the parish. The most celebrated 'folk-poem' (if that is what it is) in Irish is Caoineadh Airt Ui Laoire, 'The Lament for Art O'Leary'. This poem (which was introduced and quoted by Peter Levi in his inaugural lecture as Oxford Professor of Poetry as the greatest long poem written in these islands in the eighteenth century) existed and gestated in an unwritten form from the time of its first appearance in the 1770s until 1900. It had two authors, the widow and sister of the subject of the lament, and several adaptors. It remains uncertain what the authoritative version of the poem is, even after several generations of serious scholarly attention by authorities such as Seán Ó Tuama. This is a state of affairs which is familiar to scholars of the oral tradition, like W.J.Ong, and of course in English to students of those medieval authors of poems like Beowulf and Sir Gawain and the Green Knight. It is also a perfect instance of what the editor of Byron, Jerome McGann, says about editors trying to establish an incontestable correct text. In the process by which a satisfactory text is reached, a lot of material has to be discarded along the way - 'incorrect readings'. So what are we to do with those, like the variants in Caoineadh Airt Ui Laoghaire?

I want to turn finally to some contemporary Irish poets at the centre of the English publishing world. Paul Muldoon is a decidedly cosmopolitan writer, both before and after his move to the US as his primary domicile. If you want a striking instance of a parochial volume title, it would be hard to better Moy Sand and Gravel which clearly takes us back to the idea of putting places on the map. An equally striking example is Tom Paulin who introduces unfamiliar place-names into his poetry without the aetiological complication of the Irish language: names like Desertmartin or 'Fivemiletown', a poem which begins

The release of putting off who and where we've come from. (Fivemiletown 15)

In a note to the poem 'Fivemiletown', Paulin says 'Once named Mount Stewart, Fivemiletown was founded by the Jacobean planter Sir William Stewart early in the seventeenth century. It is now so called because it is five Irish miles from the nearest villages, Clogher, Brookeborough and Tempo' (67). This is a kind of historical aetiology.

In this context generally, the universally quoted text is Auden's 'A poet's hope: to be like some valley cheese, local, but prized elsewhere'. Auden's figure of course establishes this hope as a universal one, not Irish particularly. But I want to conclude by claiming that this universal aspiration is particularly borne in mind in Ireland: that is, to retain the mystique of locality while being 'prized elsewhere'. Muldoon is the perfect example: the poet of the parish who makes his parish the world. And the kind of etymologising, false or otherwise, or aetiological explaining, that we saw in Montague, Heaney and Friel, occurs very frequently in the wordplay that is almost the staple of Muldoon's writing. Significantly I think, it is the running conceit throughout his book of lectures To Ireland I. The fictional, cod-etymological process by which Muldoon brilliantly links Beckett to the Irish language: 
Beckett was so much taken by resonances of his own name that he would surely have delighted in that phrase in the anonymous ninth-century poem, written in the language of which Molloy speaks, 'tears and laughter, they are so much Gaelic to me.'

Berait beich

(bech a nert)

While the word beich means bees in this context, it is cognate with a number of sharpended or pointed things, including boc, a 'he-goat', and bac, a word Dinneen in his great dictionary, published in 1927, gives as meaning in Modern Irish, 'a quirk; an angular space, hollow or object; a river turn; a crozier, a mattock, a billhook, a prop, a pin, a crook, a peg, a thole-pin; a joint, a hook; a shackle, a hindrance, a stop; a firehop, a fire-prop, corner of hob; act of supporting, holding back, hindering'. The word becc means 'little, small, tiny or few'. In other words, Beich becc is a version of 'the diminutive beaked thing' of Beckett's own name. I'd like to suggest that Beckett was familiar not only with that poem...' (To Ireland I, 12)

The extraordinary thing is that Muldoon is representing Dinneen's definitions of the word bac accurately - even slightly selectively. The comedy of this passage comes through a brilliant intermediary, Flann O'Brien again, who parodies the astonishing lexical variety and creativity that Dinneen found in his local fieldresearches: in his Irish Times column O’Brien (aka Myles no Goppaleen) says 'In Donegal there are native speakers who know so many million words that it is a matter of pride with them never to use the same word twice in a life-time' (Best of Myles, 279). O'Brien contrasts this lexical richness with 'the plight of the English speaker with his wretched box of 400 vocal beads'. This shift into comedy is admissible I think because it links to Muldoon's practice in his poetry. The assumption is that the reader will not understand the references in the poetry, and that it does not matter. The same kind of inventive opacity underlies the writing of Medh McGuckian, to take another distinguished example.

This localism is dangerous terrain, I know. Many years ago I wrote an essay on Muldoon called 'The Half-said thing to them is dearest' (Kuno Meyer's description of Old Irish poets), arguing that Meyer's claim fitted Muldoon's practice very well. I am now more cautious about what a limiting idea the 'half-said thing' is, applied to what post-colonialists call a subaltern culture, and Meyer's notion was rejected early in the twentieth century by writers such as Thomas MacDonagh and Louis MacNeice, as being both essentialist and reductive. But I still think it has some aptness for the linguistic games Muldoon plays with his readers and admirers. In the poem 'The Right Arm' in his book Quoof (1963) he writes about the village called Eglish where he grew up

I would give my right arm to have known then how Eglish was itself wedged between ecclesia and église. 
Trauma, Narrative, Responsibility

In the poem '[Heidegger]' in Madoc (1990) comes this:

'I wanted merely to assure you that the name "Evans" is akin to both "Eoghan" and "Owen

Gwyneth", the father of Madoc...

We might recall too Ellmann's view of Frank O’Connor as writing of a provincial culture in terms that are not provincial but are less than cosmopolitan: a subtle description of a narrow track. Another gifted contemporary Irish poet published in England, Martina Evans, maps her route from the parish to the universal (Durras, Burnfort, Graceland). And though there is not time to go into it here, clearly the vexed matter of Irish poets decamping to English publishers is central to it. Seamus Heaney was possibly on the point of publication in Ireland when he was invited to send a manuscript to Faber and Faber: something he said was like a missive from Almighty God. A remarkable counter-case is Derek Mahon who was published by Oxford University Press as well as Gallery in Ireland. When Oxford abandoned its poetry list, Mahon did not decamp to an English publisher as most of his fellow-Oxford poets did, but settled exclusively with Gallery.

One last point might be made about this. Mahon is a classical type of writer who does not go in for opaque place-references. His famous poems with 'Co Wexford' and 'Co Cork' in their titles establish their geographical status in those titles, not leaving them as local oddities. (The village in 'A Garage in County Cork' is called 'Union Hall', but Mahon does not say so, like Gray in his 'Elegy'.) It is the language of the wider world, not defined by the local or parochial. We don't have to say that it implies the limitations of a purely local perspective, but it calls into question the universality of Kavanagh's universal. Is the parish really universal, as Kavanagh says? It is a question of loyalties and fidelity - but to what? This has been a debated issue in Irish poetry since the poets of The Nation in the 1840s: Denis Florence McCarthy's ideal in the introduction to his Book of Irish Ballads in 1846, 'That we can be thoroughly Irish in our writings without ceasing to be English; that we can be faithful to the land of our birth without being unfaithful to that literature which has been "the nursing mother of our minds"'. The most famous statement of this dilemma of loyalty is Yeats's in A General Introduction to my Work: 'though mine is the first English marriage that I know of in the direct line, all my family names are English, and .. I owe my soul to Shakespeare, to Spenser and to Blake, perhaps to William Morris, and to the English language in which I think, speak and write, that everything I love has come to me through English' (Essays and Introductions, 519). In his late play The Home Place Brian Friel satirically reverses the sense of home, making the home place of the title the English Home Counties: a reversing conceit he likes to exploit. The idea of Home Sickness is similarly undermined in George Moore's story which features a returned Irish emigrant feeling homesick for New York. The notion of the locality and the parish remains complicated.

We might return to Kavanagh for the final question: is parochialism universal? What general conclusions can we draw, either about Irish writing, or about all writing, from this exploration of (mostly Irish) texts? I began with what seems to be a positive preference for unfamiliar placenames. Of course these occur in some 
Trauma, Narrative, Responsibility

English poets too: obvious cases are William Barnes and John Clare whose practice is exactly like the Irish writers for the purposes of this argument: Helpstone, Northborough, Roundy Oak and so on. In fact Clare, the Northamptonshire poet made a great deal of a very small relocation in childhood, exactly as Heaney did. Clare's publishing experience is to the point here too. His early poems were enthusiastically championed in London by sympathetic writers like Charles Lamb, very much as Kavanagh's were, and praised for their local and parochial authenticity (Kavanagh's 'Peasant Quality' avant la lettre). But when his second volume comprised more of the same, he was warned by Lamb that 'there is a rustic Cockneyism which is as little pleasing as ours of London. Transplant Arcadia to Helpstone.' Clare, like Kavanagh, didn't know what to think; he objected to Shenstone's 'putting the correct language of a gentleman in to the mouth of a simple shepherd or vulgar ploughman' as 'far from natural'. So no doubt Heaney was right to say that the sense of place was not uniquely Irish; but the self-conscious rural-derived Irish writers exemplify the case exceptionally well - better perhaps than any English poet except John Clare. 